\title{
ОРГАНІЗАЦІЯ ЕКСПЕРИМЕНТАЛЬНОГО ДОСЛІДЖЕННЯ ТА АНАЛІЗ РЕЗУЛЬТАТІВ РОЗВИТКУ ПРОФЕСІЙНОГО ПОТЕНЦІАЛУ МАЙБУТНІХ ВЧИТЕЛІВ ІНОЗЕМНИХ МОВ У ПРОЦЕСІ ФАХОВОӤ ПІДГОТОВКИ
}

У статті висвітлено особливості організації та проаналізовано результати експериментального дослідження перевірки результативності реалізачї̈ педагогічних умов і структурно-функціональної моделі розвитку професійного потенціалу майбутніх вчителів іноземних мов у процесі фахової підготовки.

Резюмовано, щчо проведення експериментального дослідження відбувалося протягом 2016-2020 років й охоплювало чотири етапи: теоретико-аналітичний, констатувальний, виконавчий (формувальний), результативно-аналітичний. На теоретико-аналітичному етапі встановлено актуальність досліджуваної проблеми; визначено мету, об'єкт, предмет, завдання дослідження; конкретизовано наукові підходи і висвітлено можливості використання освітнього контексту професійної підготовки майбутніх вчителів іноземних мов як середовища для розвитку професійного потенціалу студентів.

На констатувальному етапі досягнуто таких основних результатів: розроблено авторський діагностичний інструментарій для визначення сформованості професійного потениіалу майбутніх вчителів іноземних мов; конкретизовано компоненти, критерії, показники, рівні професійного потенціалу майбутніх вчителів іноземних мов; визначено і теоретично обтрунтовано комплекс педагогічних умов та розроблено структурно-функціональну модель розвитку професійного потенціалу майбутніх вчителів іноземних мов у процесі фахової підготовки.

Виконавчий (формувальний) етап педагогічного експерименту проводився зі студентами ІІІ курсу. Основною метою проведення цьього етапу була реалізація комплексу педагогічних умов і структурно-функціональної моделі розвитку професійного потенціалу майбутніх вчителів іноземних мов у процесі фахової підготовки.

На результативно-очінювальному етапі педагогічного дослідження оброблено та проаналізовано отримані дані, здійснено порівняльний аналіз ефективності традиційної та експериментальної методики розвитку професійного потенціалу майбутніх вчителів іноземних мов у процесі фахової підготовки.

Ключові слова: потенціал, професійний потенціал, компонент, етап, організація, майбутні вчителі іноземних мов.

\author{
Katalin HNATYK, \\ orcid.org/0000-0003-4975-6266 \\ Lecturer at the Department of Philology \\ Ferenc Rakoczi II Transcarpathian Hungarian College of Higher Education \\ (Beregovo, Transcarpathian region, Ukraine) \\ $2^{\text {nd }}$ year PhD Student at the Faculty of Humanities at the Department \\ of English Philology and Methods of Teaching Foreign Languages \\ Mukachevo State University \\ (Mukachevo, Transcarpathian region, Ukraine) mesterkati29@gmail.com
}

\section{EXPERIMENTAL RESEARCH AND ANALYSIS ON THE ISSUE OF THE DEVELOPMENT OF FUTURE FOREIGN LANGUAGE TEACHERS' PROFESSIONAL POTENTIAL}

The article highlights the features of the results and analysis of an experimental study to verify the effectiveness of the implementation of pedagogical conditions and structural and functional model of professional development of future foreign languages teachers in the professional training process.

It is summarized that the experimental study took place during 2016-2020 and covered four stages: theoreticalanalytical, ascertaining, executive (formative), analytical-resultative. At the first (theoretical-analytical) stage the 
urgency of the researched problem is established; the purpose, object, subject, tasks of research are defined; scientific approaches are specified and the possibilities of using the educational context of professional training of future foreign language teachers as an environment for the development of students' professional potential are highlighted.

At the ascertaining stage, the following main results were achieved: the author's diagnostic tools for determining the formation of future foreign language teachers 'professional potential were developed; the components, criteria, indicators, levels of future foreign language teachers' professional potential are specified; the complex pedagogical conditions are determined, theoretically substantiated and the structural-functional model of the development of future foreign language teachers 'professional potential in the professional training process is developed.

The executive (formative) stage of the pedagogical experiment was conducted with third-year students. The main purpose of this stage was the implementation of a set of pedagogical conditions and structural and functional model of the development of future foreign language teachers ' professional potential in the professional training process.

At the effective and evaluative stage of pedagogical research the received data are processed and analyzed. Throughout the comparative analysis the efficiency of traditional and experimental methods used in the development of future foreign languages teachers' professional potential is carried out.

Key words: potential, professional potential, component, stage, organization, future foreign language teachers.

Постановка проблеми. Дослідно-експериментальна перевірка результативності реалізації педагогічних умов і структурно-функціональної моделі розвитку професійного потенціалу майбутніх вчителів іноземних мов у процесі фахової підготовки відбувалася шляхом проведення педагогічного експерименту, який охоплював кілька етапів наукової розвідки. Планування основних етапів пошукової роботи дало змогу найоптимальнішим шляхом досягнути поставленої наукової мети, оскільки зосереджувалося на врахуванні загальної логіки дослідницької діяльності.

Аналіз досліджень. Проблема розвитку професійно-педагогічного потенціалу як якості особистості, яка характеризується стійким інтересом до професії вчителя у єдності із суспільною і пізнавальною активністю, що виявляється у прагненні та готовності відповідально виконувати свої педагогічні обов'язки та функції, знайшла відображення в сучасних наукових доробках науковців (Антонова, 2006: 553-561).

Деякі науковці актуалізують проблему пояснення педагогічного потенціалу крізь призму педагогічної спрямованості (Алікберов, 2016: 20-22; Антонов, 2009: 16-28; Кікінеджі, 2012; Кононов, 2013: 5-27; Ложкін, 2008: 123-130 та інші). Однак цілеспрямованих наукових розвідок у напрямі розвитку професійного потенціалу майбутніх вчителів іноземних мов у процесі фахової підготовки ми не знайшли. Тому було проаналізовано джерела, які містять експериментально перевірені відомості про методику дослідницької роботи в рамках педагогічних розвідок (Батаршев, 2007; Киверялг, 1980; Лузан, 2011; Штульман, 1988: 61-65).

Мета статті - окреслення ключових віх розгортання експериментального дослідження перевірки результативності реалізації педагогічних умов та структурно-функціональної моделі розвитку професійного потенціалу майбутніх вчителів іноземних мов у процесі фахової підготовки.
Виклад основного матеріалу. Організація проведення експериментального дослідження здійснювалася протягом 2016-2020 років й охоплювала чотири етапи: теоретико-аналітичний, констатувальний, виконавчий (формувальний), результативно-аналітичний. Охарактеризуємо їх детальніше.

На теоретико-аналітичному етапі здійснено такі кроки: встановлено актуальність проблеми розвитку професійного потенціалу майбутніх вчителів іноземних мов у процесі фахової підготовки; визначено мету, об'єкт, предмет, завдання дослідження; висвітлено можливості використання освітнього контексту професійної підготовки майбутніх вчителів іноземних мов як середовища для формування професійного потенціалу; конкретизовано наукові підходи до проблеми розвитку професійного потенціалу майбутніх вчителів іноземних мов під час навчання.

У процесі проведеної роботи на констатувальному етапі досягнуто таких основних результатів: розроблено авторський діагностичний інструментарій для визначення професійного потенціалу майбутніх вчителів іноземних мов; конкретизовано компоненти, критерії, показники, рівні сформованості професійного потенціалу майбутніх вчителів іноземних мов; визначено і теоретично обгрунтовано комплекс педагогічних умов та розроблено структурно-функціональну модель розвитку професійного потенціалу майбутніх вчителів іноземних мов у процесі фахової підготовки.

Констатувальний етап дослідження передбачав здійснення діагностики сучасного стану професійного потенціалу майбутніх вчителів іноземних мов на основі конкретизованих компонентів, критеріїв, показників і рівнів. Основною метою діагностики, яка здійснювалася шляхом комплексного використання багатьох методів, було встановлення стану сформованості різних аспектів, які визначають професійно-особистісні характеристики студентів 
за чотирма компонентами професійного потенціалу (аксіологічно-мотиваційний, когнітивний, комунікативно-мовний, рефлексивний).

У констатувальному етапі дослідження, який проводився протягом 2016-2017 н.р., брали участь студенти, які здобували освітньо-кваліфікаційний рівень бакалавра в галузі знань 01 «Освіта» за напрямом 014 Середня освіта (Англійська мова та зарубіжна література) і на момент залучення їх до участі в експериментальному дослідженні завершували навчання на III курсі. Апелюючи до складної багатокомпонентної структури професійного потенціалу, було прийнято рішення стосовно дослідження рівня сформованості такого феномену у майбутніх вчителів іноземних мов i застосування низки взаємодоповнюючих методик, які склали комплекс діагностичних методичних матеріалів. Так, використовувалися авторські розробки та адаптовані автором варіанти існуючих методик; зрізи знань (контрольні роботи, тестування) для визначення глибини, системності, інтегративності фахових знань студентів.

Детальний теоретичний аналіз наукової літератури підтвердив існування значної кількості діагностичних методик, які дослідники активно застосовують для визначення сформованості тих чи інших якостей. Однак комплексних методичних матеріалів для встановлення рівнів сформованості професійного потенціалу майбутніх вчителів іноземних мов ми не знайшли, тому адаптували відомі та розробляли авторські діагностичні матеріали для діагностування заданого феномену. Враховувалися вимоги до об'єктивності, валідності, надійності результатів. Був розроблений комплекс методик, сконструйований таким чином, щоб виявити стан усіх показників досліджуваного феномену. В подальшому обраний діагностичний інструментарій застосовувався під час вхідного та підсумкового контролю на формувальному етапі експериментального дослідження. Це дало змогу забезпечити однакові вимоги до студентів, які завершили вивчення обраних дисциплін, і критерії оцінювання сформованості професійного потенціалу майбутніх вчителів іноземних мов до і після використання авторських навчально-методичних матеріалів.

Отримані результати діагностичного (констатувального) етапу педагогічного експерименту вказують на необхідність інноватизації, активізації, модернізації фахової підготовки майбутніх вчителів іноземних мов у напрямі розвитку професійного потенціалу студентів. На формувальному етапі експериментального дослідження реалізовано педагогічні умови та структурно- функціональну модель розвитку професійного потенціалу майбутніх вчителів іноземних мов у процесі фахової підготовки.

Виконавчий (формувальний) етап педагогічного експерименту проводився протягом 2017-2018 та 2018-2019 н.pp. зі студентами II та III курсу, які здобувають освітньо-кваліфікаційний рівень бакалавра в галузі знань 01 «Освіта» за напрямом 014 Середня освіта (Англійська мова та зарубіжна література). Основною метою проведення цього етапу була реалізація взаємопов'язаних педагогічних умов і структурно-функціональної моделі розвитку професійного потенціалу майбутніх вчителів іноземних мов у процесі фахової підготовки. Для досягнення мети проведено такі заходи:

- майбутніх вчителів іноземних мов, які стали учасниками експерименту, розподілено на контрольні (далі - КГ) та експериментальні (далі ЕГ) групи;

- здійснено вхідний контроль (далі - ВК) для встановлення рівня сформованості професійного потенціалу студентів на момент вступу в експеримент;

- сконструйовано методичні рекомендації для викладачів щодо розвитку професійного потенціалу майбутніх вчителів іноземних мов у процесі фахової підготовки;

- здійснено розробку, апробацію та перевірку ефективності педагогічних умов і структурнофункціональної моделі розвитку професійного потенціалу майбутніх вчителів іноземних мов у процесі фахової підготовки.

Розподіл студентів на ЕК та КГ здійснювався 3 урахуванням певних особливостей, дотримання яких гарантувало однакові умови вступу майбутніх вчителів іноземних мов в експеримент. Такими чинниками визначено цифрові показники сформованості усіх компонентів професійного потенціалу студентів цієї спеціальності та кількісний склад осіб в обох категоріях груп, які були майже ідентичними. На основі аналізу результатів ВК встановлено, що сформованість усіх компонентів професійного потенціалу у студентів КГ та ЕГ має близькі значення. Це підтверджує однакові умови вступу майбутніх вчителів іноземних мов у педагогічний експеримент.

Результативно-оцінювальний (аналітичний) (2020 рік) етап педагогічного дослідження характеризувався такими віхами:

- проведено експериментальну перевірку ефективності імплементації педагогічних умов та структурно-функціональної моделі розвитку професійного потенціалу майбутніх вчителів іноземних мов у процесі фахової підготовки; 
- проаналізовано отримані статистичні дані, здійснено порівняльний аналіз ефективності традиційної методики розвитку професійного потенціалу майбутніх вчителів іноземних мов у процесі фахової підготовки та реалізації запропонованих у дослідженні педагогічних умов такого процесу;

- систематизовано й узагальнено результати експериментального дослідження; доведено їх вірогідність шляхом використання методів математичної статистики;

- сформульовано висновки; визначено перспективи подальших розвідок у напрямі інноватизації процесу розвитку професійного потенціалу майбутніх вчителів іноземних мов у процесі фахової підготовки.

Уточнення цифрових показників рівнів сформованості усіх компонентів професійного потенціалу майбутніх вчителів іноземних мов на етапі підсумкового контролю здійснювалося після вивчення студентами обраних для експериментального дослідження дисциплін, у процесі вивчення яких студенти експериментальних груп брали участь у виконанні інноваційних вправ (спрямованих на формування усіх компонентів професійного потенціалу), а студенти контрольних груп здобували освіту в умовах традиційного навчання.

Аналіз отриманих даних на етапах вхідного та підсумкового контролю дає змогу зазначити, що у контрольних та експериментальних групах не було студентів, у яких рівні професійного потенціалу майбутніх вчителів іноземних мов у цифровому еквіваленті менші за 60 балів. Вірогідність отриманих результатів і достовірність експериментального дослідження доведено з використанням статистичних методів обробки даних педагогічного експерименту. 3 цією метою враховувалися наукові підходи дослідників, які визначають допустиму найменшу кількість осіб в експериментальній групі. Так, за Е. Штульманом доцільно використовувати в методичних експериментах поняття «малої вибірки», згідно з яким для порівняння результатів в експериментальних і контрольних групах досить мати по 24 особи, оскільки математична статистика стверджує, що після цього числа порівнювальні дані починають повторюватися (Штульман, 1988: 64). Кількість студентів у контрольних й експериментальних групах була цілком достатньою для доведення вірогідності результатів експериментального дослідження.

3 метою перевірки гіпотези дослідження засобами математичної статистики використовувалося порівняння дисперсій за допомогою F-критерію за формулою 1 (Киверялг, 1980: 277):

$$
F_{\text {emp }}=\frac{\sigma_{1}^{2}}{\sigma_{2}^{2}},
$$

Основними складниками цієї формули є:

$\mathrm{F}_{\text {emp }}$ - емпіричне (обчислене за результатами експериментальних даних) значення F-критерію для контрольних та експериментальних груп, величина якого порівнювалася з показниками теоретичного F-критерію $\left(\mathrm{F}_{k r i t}\right)$;

$\sigma_{1}^{2}-$ цифровий показник більшої дисперсії;

$\sigma_{2}^{2}-$ цифровий показник меншої дисперсії.

Значення дисперсії обчислювалися при вхідному та підсумковому визначенні рівнів сформованості професійного потенціалу майбутніх вчителів іноземних мов за формулою 2 :

$$
\sigma^{2}=\frac{\sum f\left(x_{i}-\bar{x}\right)^{2}}{N}
$$

де $f$ - кількість студентів, які виявили певний рівень сформованості професійного потенціалу, що має цифровий вираз для математичних розрахунків у п’ятибальній системі (високий - 5 балів; достатній - 4 бали; задовільний - 3 бали; низький -2 бали);

$\left(x_{i}-\bar{x}\right)-$ різниця між цифровими значеннями кожного рівня та величиною середнього показника (далі - СП);

$\mathrm{N}$ - загальна кількість студентів у тих категоріях груп (контрольних чи експериментальних), де обчислюється дисперсія.

Для перевірки достовірності отриманих результатів ми порівнювали обчислені і визначені показники емпіричного F-критерію у контрольних $\left(\mathrm{F}_{\text {emp }}-\mathrm{K} Г\right)$ та експериментальних групах $\left(\mathrm{F}_{\text {emp }}\right.$-ЕГ) 3 показниками теоретичного F-критерію $\left(\mathrm{F}_{k r i t}\right)$, числові значення якого відображені у стандартній таблиці (Киверялг, 1980: 278).

Статистичні дані свідчать, що за умови, коли число ступенів свободи (кількість студентів у групі мінус 1) буде в межах від 24 до безкінечності та від 60 до 120 (у нашому дослідженні це відповідає кількості студентів у контрольних та експериментальних групах на етапах вхідного та підсумкового контролю), то показник $\mathrm{F}_{k r i t}$ має перебувати в межах таких цифрових даних: 1,71,3. Порівняльний аналіз емпіричного показника F-критерію контрольних та експериментальних груп 3 визначеними межами $\mathrm{F}_{k r i t}$ показав, що $\mathrm{F}_{\text {emp }}-$ КГ виходить за вказані межі, а $\mathrm{F}_{\text {emp }}$-ЕГ підтверджує достовірність отриманих результатів.

Висновки. Отже, експериментальне дослідження перевірки результативності реалізації педагогічних умов та структурно-функціональної моделі розвитку професійного потенціалу майбутніх вчителів іноземних мов у процесі 
фахової підготовки здійснювалося протягом 2016-2020 років й охоплювало чотири етапи: теоретико-аналітичний, констатувальний, виконавчий (формувальний), результативно-аналітичний. Результати, отримані в процесі експериментальної роботи, свідчать про ефективність і доцільність впровадження у навчальний процес закладів вищої освіти запропонованих педагогічних умов та структурно-функціональної моделі.

Перспективи подальших розвідок у цьому напрямі вбачаємо в окресленні особливостей реалізації методики розвитку професійного потенціалу майбутніх вчителів іноземних мов у процесі фахової підготовки.

\section{СПИСОК ВИКОРИСТАНИХ ДЖЕРЕЛ}

1. Алікберов Р. Д. Соціокультурна ідентичність: соціально-філософський аналіз. Правові та інституиійні механізми забезпечення розвитку держави та права в умовах євроінтегращії : матеріали Міжнар. наук.-практ. конф. (м. Одеса, 20 травня 2016 року). Одеса : Юридична література, 2016. С. 20-22.

2. Антонова Н. В. Особливості професійної ідентичності студентів психологічного факультету. Проблеми загальної та педагогічної психології. 2009. Вип. ХІ. (4). С. 16-28.

3. Антонова О. Є. Розвиток творчого потенціалу майбутнього вчителя як фактор його професійної самореалізації. Життєтворчість особистості: концепиія, досвід, проблеми : наук.-метод. зб. / За ред. І. Г. Срмакова, Г. М. Несен. Запоріжжя : Хортицький навчально-реабілітаційний багатопрофільний центр, 2006. С. 553-561.

4. Батаршев А. В., Алексеева И. Ю., Майорова Е. В. Диагностика профессионально-важных качеств. СПб. : Питер, 2007. 192 с.

5. Кікінежді О. М. Ідентифікація як соціально-психологічний феномен диференціації статі : дис. доктора псих. наук: 19.00.07 / Нац. пед. ун-тет $\quad$ ім. М. П. Драгоманова. Київ, 2012. 422 с.

6. Кононов I. Ф. Концепція ідентифікації та ідентичності у психоаналізі: Зигмунд Фройд та Ерік Еріксон. Вісник Луганського наиіонального університету імені Тараса Шевченка. Серія: Соиіологічні науки. 2013. № 23(3). С. 5-27.

7. Кыверялг А. А. Методы исследования в профессиональной педагогике. Таллин : «Валгус», 1980. 334 с.

8. Ложкін Г. В., Волянюк Н. Р. Професійна ідентичність в контексті маргінальної поведінки суб’єкта. Соціальна психологія. 2008. № 3. С. 123-130.

9. Лузан П. Г., Сопівник І. В., Виговська С. В. Основи науково-педагогічних досліджень. К. : НАКККіМ, 2011.314 с.

10. Штульман Э. А. Специфика методического эксперимента. Сов. педагогика. 1988. № 3. С. 61-65.

\section{REFERENCES}

1. Alikberov R. D. (2016) Sotsiokulturna identychnist: sotsialno-filosofskyi analiz [Sociocultural identity: socio-philosophical analysis]. Pravovi ta instytutsiini mekhanizmy zabezpechennia rozvytku derzhavy ta prava $\mathrm{v}$ umovakh yevrointehratsii [Legal and institutional mechanisms for ensuring the development of the state and law in the context of European integration: materials International] : materialy Mizhnar. nauk.-prakt. konf. (m. Odesa, 20 trav. 2016 r.). Odesa : Yurydychna literatura. S. 20-22 [in Ukraine].

2. Antonova N. V. (2009) Osoblyvosti profesiinoi identychnosti studentiv psykholohichnoho fakultetu [Features of professional identity of students of the Faculty of Psychology]. Problemy zahalnoi ta pedahohichnoi psykholohii [Problems of general and pedagogical psychology]. Vyp. KhI. (4). S. 16-28 [in Ukraine].

3. Antonova O. Ye. (2006) Rozvytok tvorchoho potentsialu maibutnoho vchytelia yak faktor yoho profesiinoi samorealizatsii [Development of creative potential of the future teacher as a factor of his professional self-realization]. Zhyttietvorchist osobystosti: kontseptsiia, dosvid, problemy [Life-creating personality: concept, experience, problems] : Nauk.-metod. zb. / Za red. I. H. Yermakova, H. M. Nesen. Zaporizhzhia : Khortytskyi navchalno-reabilitatsiinyi bahatoprofilnyi tsentr. S. 553-561 [in Ukraine].

4. Batarshev A. V., Alekseeva Y. Yu., Maiorova E. V. (2007) Dyahnostyka professyonalno vazhnykh kachestv [Diagnosis of professionally important qualities]. SPb. : Pyter, $192 \mathrm{~s}$. [in Russian].

5. Kikinezhdi O. M. (2012) Identyfikatsiia yak sotsialno-psykholohichnyi fenomen dyferentsiatsii stati [Identification as a socio-psychological phenomenon of gender differentiation] : dys. doktora psykh. nauk: 19.00 .07 / Nats. ped. un-tet im. M. P. Drahomanova. Kyiv. 422 s. [in Ukraine].

6. Kononov I. F. (2013) Kontseptsiia identyfikatsii ta identychnosti v psykhoanalizi: Zygmund Froid ta Erik Erikson [The concept of identification and identity in psychoanalysis: Sigmund Freud and Eric Erickson]. Visnyk Luhanskoho natsionalnoho universytetu imeni Tarasa Shevchenka [Bulletin of Luhansk Taras Shevchenko National University]. Ser.: Sotsiolohichni nauky. № 23 (3). S. 5-27 [in Ukraine].

7. Kuverialh A. A. (1980) Metodu yssledovanyia v professyonalnoi pedahohyke [Research methods in professional pedagogy]. Tallyn : "Valhus". 334 s. [in Russian].

8. Lozhkin H. V., Volianiuk N. R. (2008) Profesiina identychnist v konteksti marhinalnoi povedinky subiekta [Professional identity in the context of marginal behavior of the subject]. Sotsialna psykholohiia [Social Psychology]. № 3. S. $123-130$ [in Ukraine].

9. Luzan P. H., Sopivnyk I. V., Vyhovska S. V. (2011) Osnovy naukovo-pedahohichnykh doslidzhen [Fundamentals of scientific and pedagogical research]. K. : NAKKKiM. 314 s. [in Ukraine].

10. Shtulman E. A. (1988) Spetsyfyka metodycheskoho eksperymenta [Specifics of the methodical experiment]. Sov. pedahohyka. № 3. S. 61-65 [in Russian]. 